\title{
Proteomic analysis to identify candidate biomarkers associated with type I diabetes
}

This article was published in the following Dove Press journal: Diabetes, Metabolic Syndrome and Obesity:Targets and Therapy

\begin{abstract}
Valzimeire do Nascimento de Oliveira, ${ }^{1,2}$ Abelardo Barbosa Moreira LimaNeto,' Maurício Fraga van Tilburg, ${ }^{2}$ Ana Cristina de Oliveira MonteiroMoreira, ${ }^{3}$ Marina Duarte Pinto Lobo, ${ }^{3}$ Davide Rondina, ${ }^{4}$ Virgínia Oliveira Fernandes, ${ }^{5}$ Ana Paula Dias Rangel Montenegro, ${ }^{5}$ Renan Magalhães Montenegro Júnior, ${ }^{5}$ Maria Izabel Florindo Guedes ${ }^{1,2}$

'Collegiate Nutrition Science, Laboratory of Biotechnology and Molecular Biology, Ceará State University, Fortaleza, Ceará, Brazil; ${ }^{2}$ Collegiate Biotechnology, Northeast Network of Biotechnology, Laboratory of Biotechnology and Molecular Biology, Ceará State University, Fortaleza, Ceará, Brazil; ${ }^{3}$ Center of Experimental Biology, University of Fortaleza, Fortaleza, Ceará, Brazil; ${ }^{4}$ School of Veterinary Science, Ceará State of University, Fortaleza, Ceará, Brazil; ' ${ }^{5}$ Faculty of Medicine, Federal University of Ceará and University Hospitals, Fortaleza, Ceará, Brazil
\end{abstract}

Correspondence: Valzimeire do Nascimento de Oliveira Av. Dr. Silas Munguba, I700, Campus do Itaperi, bloco D, $I^{0}$ andar, Sala 0I, Laboratório de Biologia Molecular e Biotecnologia, Fortaleza, Ceará, Brazil Tel +55 85 9999l 3404

Email valzimeire.oliveira@uece.br
Purpose: Type 1 diabetes mellitus (DM1) is one of the most common chronic diseases observed during childhood. The incidence of DM1 is increasing worldwide, and there is currently no way to prevent or delay the onset or to cure the disease. Most diseases, including diabetes, stem from abnormalities in the functioning of proteins, and some studies have reported the expression of protein variation to be involved in the development of DM1. Thus, the aim of this study was to investigate the differential expression of serum proteins in patients with DM1.

Materials and methods: Serum of patients with DM1 $(n=30)$ and healthy controls $(n=30)$ was collected. A proteomic approach was used with depletion of albumin and immunoglobulin $\mathrm{G}$ chromatography on serum samples followed by data-independent, label-free mass spectrometric analysis.

Results: A total of eight serum proteins were identified as being differentially expressed and involved in the immune system, lipid metabolism, and pathways of coagulation. DM1 was associated with the upregulation of six proteins: alpha-2-macroglobulin, apolipoprotein A-II, $\beta 2$ glycoprotein I, Ig alpha- 2 chain $\mathrm{C}$ region, alpha-1-microglobulin, and prothrombin. A total of two proteins were downregulated, including pregnancy zone protein and complement $\mathrm{C} 4$.

Conclusion: To the best of our knowledge, these findings show differential expression of proteins revealing new proteins that may be involved in the development and progression of diabetes.

Keywords: proteome, mass spectrometry, precision medicine, diagnosis

\section{Introduction}

Type 1 diabetes mellitus (DM1) is characterized by the destruction of insulin-producing $\beta$-cells in the pancreas, with consequent insulin deficiency. ${ }^{1}$ It is a metabolic and endocrine condition more common in childhood development and is preceded by the dysregulation of many biological pathways. ${ }^{2}$ At present, no therapy exists to halt the immune-mediated destruction of $\beta$-cells, ${ }^{3}$ and DM1 has a substantial long-term impact on the quality of life, particularly in children and adolescents.

According to the International Diabetes Federation, ${ }^{4}$ the total population with DM was equivalent to 415 million and is estimated to increase to 471 million by 2035 . A recent report of World Health Organization estimated that, globally, 422 million adults aged $>18$ years were living with diabetes in 2014, compared with 108 million in $1980 . .^{5}$ Following the same trend, the incidence of DM1 has increased by $\sim 3 \%$ worldwide and represents $5 \%-10 \%$ of the entire population with diabetes. ${ }^{6}$

There has been a lot of research conducted on diabetes over the decades. Several proteomic approaches have been undertaken to identify biomarkers for monitoring the 
prediction $^{7,8}$ and progression ${ }^{9}$ of the disease. However, there are some limitations due to low specificity or late application to the disease stage. ${ }^{10}$

DM1 is a complex disease with altered expression of many genes and their products. ${ }^{11}$ Therefore, different approaches were developed using current proteomic technologies to explore its clinical potential and enable the discovery of new biomarkers for DM1.

Recent advances in proteomics have triggered rapid progress in mass spectrometry (MS)-based proteomics. It enables more than simple protein identification and can accurately and reliably quantitate differences in protein abundance in an organism, a cell, or a tissue at a given time or under a particular condition. ${ }^{12}$ The label-free technique has been shown to be more accurate in estimating absolute abundance of proteins in complex samples. ${ }^{13}$

In the current study, we performed a quantitative and qualitative analysis using a sample pretreatment immunodepletion of serum albumin and immunogloblin $\mathrm{G}$ (IgG) combined with data-independent label-free mass spectrometry $\left(\mathrm{MS}^{\mathrm{E}}\right)$ analysis with the aim of identifying differentially expressed levels of serum proteins in DM1 patients and healthy controls (HCs).

\section{Materials and methods Study participants}

The present study enrolled DM1 patients selected among those in a regular follow-up in the outpatient of Endocrinology and Diabetes at the Federal University Hospital of Ceara, Fortaleza, Brazil. DM1 patients aged $\geq 18$ years, both male and female, who had attended the outpatient department of Endocrinology and Diabetes for a minimum of 6 months, with clinical and cognitive conditions to answer an interview and the capacity to stand up normally were eligible for the DM1 group. Patients using immunosuppressive medications (renal, heart, or hepatic dysfunction; type 2 diabetes; etc.); those with alcoholism and mental disorders (including dementia and Alzheimer's disease); those diagnosed with leprosy or HIV infection; and those with autoimmune disease, amputation or ulcers on the lower limbs, acute infectious frames, or diabetic ketoacidosis in the 3 months preceding the evaluation, as well as pregnant or lactating females, were excluded. HCs were selected from the Federal University and Ceará State University, considering the same criteria used for DM1 patients, besides not having a familiar history of diabetes and with fasting blood glucose $\leq 99 \mathrm{mg} / \mathrm{dL}$.

The study initially enrolled all patients attending the outpatient department as potential participants. After applying rigorous inclusion and exclusion criteria to achieve a group with highly homogeneous clinical features and accounting for loss during the selection process, a total of 60 subjects were included as study participants: $30 \mathrm{DM} 1$ patients and 30 HCs. The DM1 and HC groups were matched by gender, age, body mass index (BMI), total cholesterol, high-density lipoprotein cholesterol (HDL-C), serum low-density lipoprotein cholesterol (LDL-C), total protein, urea, and creatinine. General health features, demographics, and clinical data were obtained through medical records and direct interviews. The study protocol (number 1357544) was approved by the Federal University Hospital of Ceará Ethics Committee, and the study was conducted according to the principles of the Declaration of Helsinki. Written informed consent was obtained from all the participants.

\section{Anthropometry and health-related behaviors}

Weight and height were measured according to the SISVAN (Food and Nutritional Surveillance System; 2004). ${ }^{14}$ BMI was calculated as weight (in $\mathrm{kg}$ ) divided by height (in $\left.\mathrm{m}^{2}\right) .{ }^{15}$ The considered standard doses for alcohol consumption and categories were in accordance with World Health Organization. ${ }^{16}$ Cigarette smoking status was consistent with that shown in Vital and Health Statistics. ${ }^{17}$

\section{Serum samples}

Blood samples were collected from all subjects after an overnight fast (12 hours) for biochemical analysis. All the samples were centrifuged at $3000 \mathrm{rpm}$ for 15 minutes at room temperature, and the serum obtained was kept frozen at $-80^{\circ} \mathrm{C}$ until analyzed. Fasting blood sugar, total cholesterol, HDL-C, triglyceride, urea, and creatinine were measured by colorimetric enzymatic method using commercially available kits (Bioclin, Quibasa Quimica Basica Ltda, Belo Horizonte, Minas Gerais, Brazil) and an automated biochemical analyzer (Mindray BC-2800; Shenzhen Mindray Bio-Medical Electronics Co. Ltd., Shenzhen, China). LDL-C was calculated using the Frederickson-Friedewald equation. ${ }^{18} \mathrm{C}$-peptide analysis was performed by immunoassays of microparticles by quimioluminescence (Kit ARCHITECT C-Peptide) using Architec Asystema no. i2000 (Chicago, IL, USA). Samples were analyzed in triplicate.

The serum protein concentration was determined by the Bradford method. ${ }^{19}$ The serum samples were pooled in the same group for proteomic analysis. Using $5.33 \mu \mathrm{g}$ of protein from each individual sample, 15 samples were pooled to form each group of patients with diabetes and the HC groups. Therefore, 
two pools of samples from patients with DM1 (DM1a and $\mathrm{DM} 1 \mathrm{~b})$ and two pools of $\mathrm{HCs}(\mathrm{HCa}$ and $\mathrm{HCb}$ ) were generated.

\section{Immunodepletion of high-abundance proteins}

In order to improve the chance of detecting a wide range of serum proteins of medium to low abundance, proteins of high abundance, albumins, and immunoglobulins were depleted from the serum. Aliquots of serum were filtered through 0.22- $\mu \mathrm{M}$ membrane (KASVI, São José do Pinhais, Brazil). Then, $150 \mu \mathrm{L}$ of filtered serum was applied to a HiTrap ${ }^{\circledR}$ Albumin \& IgG Depletion column (GE Healthcare BioSciences Corp., Piscataway, NJ, USA) attached to an AKTA Purifier 10 fast protein liquid chromatography system (GE Healthcare). The column was preequilibrated with a solution of $20 \mathrm{mM}$ Tris- $\mathrm{HCl}(\mathrm{pH} 7.4)$ and $0.15 \mathrm{M} \mathrm{NaCl}$. The elution of fraction rich in albumin and immunoglobulin was realized with 0.1 M Glycine-HCL buffer ( $\mathrm{pH}$ 2.7) delivered at $1 \mathrm{~mL} /$ min, and absorbance was monitored at 216 and $280 \mathrm{~nm}$.

\section{Nano-ultra performance liquid chromatografy MS analysis}

After immunodepletion, the fractions of the pools were dialyzed, concentrated, and quantified using a Vivaspin ${ }^{\mathrm{TM}}$ (GE Healthcare) and a NanoVue ${ }^{\mathrm{TM}}$ Spectrometer (GE Healthcare), respectively, at an absorbance at $280 \mathrm{~nm}$. The denatured samples $(100 \mu \mathrm{g})$ were diluted in $50 \mathrm{mM}$ ammonium bicarbonate, denatured with a solution of $0.2 \%$ RapiGest $^{\mathrm{TM}} \mathrm{SF}$ (Waters Corporation, Milford, MA, USA) at $80^{\circ} \mathrm{C}$ for 15 minutes in a dry bath, and reduced with $100 \mathrm{mM}$ dithiothreitol at $60^{\circ} \mathrm{C}$ for 60 minutes, and alkylation with $300 \mathrm{mM}$ iodoacetamide for 30 minutes was performed in the dark at room temperature. The digestion occurred with the addition of $1 \mu \mathrm{g}$ of modified trypsin (Promega, Madison, WI, USA) to each sample at $37^{\circ} \mathrm{C}$, and the samples were incubated overnight. The reaction was stopped by adding $10 \mu \mathrm{L}$ of $5 \%$ of trifluoroacetic acid, the samples were incubated for 90 minutes at $37^{\circ} \mathrm{C}$, centrifuged, and the supernatant was transferred to vial (Waters, Manchester, UK). Tryptic peptides of yeast alcohol dehydrogenase $(\mathrm{ADH})$ were added to vials containing digested proteins to a final concentration of $50 \mathrm{fmol} / \mu \mathrm{L}$ as internal standards. The final protein concentration was $\sim 1 \mu \mathrm{g} / \mu \mathrm{L}$.

The tryptic peptides were separated using a nanoACQUITY UPLC ${ }$ system (Waters) equipped with an HSS T3 C18 reverse-phase column $(1.8 \mu \mathrm{m}, 75 \mu \mathrm{m} \times 20 \mathrm{~mm}$; Waters $)$ for 110 minutes using $0 \%-40 \%$ gradient for 90 minutes and $40 \%-85 \%$ for 5 minutes. The column was reequilibrated for 15 minutes at $35^{\circ} \mathrm{C}$. The flow rate was $0.35 \mu \mathrm{L} / \mathrm{min}$, and mobile Phases A and B contained $0.1 \%$ formic acid in water and $0.1 \%$ formic acid in acetonitrile, respectively. All the samples were measured in triplicate. $\mathrm{MS}^{\mathrm{E}}$ was performed using a Synapt HDMS (nano-electrospray ionization quadrupole /orthogonal acceleration time-of-flight mass spectrometer; Waters, Manchester, UK). The equipment was operated in "V" mode with a precursor double-charge resolution $\geq 10,000$ full width at half maximum and in electrospray positive-ion mode nano-electrospray ionization $(+)$. Mass spectrometer data were acquired using a NanoLockSpray probe channel infusion of Glu-fibrinogen peptide (Glu-Fib) derived from fibrinopeptide $\mathrm{B}$ human $(\mathrm{M}+2 \mathrm{H})^{2}$ and final calibration of the equipment used MS/MS Glu-Fib fragments.

\section{Data processing and protein identification and quantification}

Liquid chromatography (LC)/MS ${ }^{\mathrm{E}}$ data were processed, and the proteins were identified using the ProteinLynx Global Server (PLGS) version 2 software with the UniProt reverse Homo sapiens annotated database. For searching spectra and the database, the default parameters of PLGS were used, followed by a maximum of one missed trypsin cleavage. The absolute quantification of each run was calculated according to the three most intense peptides (label-free $\mathrm{Hi} 3$ method) using ADH peptides as internal standards. ${ }^{13}$ Relative quantification of identified proteins from each expression group was performed using alpha-1-antitrypsin (UniProt) as an internal common housekeeping protein to normalize expression levels, using PLGS Expression ${ }^{\mathrm{E}}$ software (Waters). ${ }^{20}$ The average quantitative values of all the samples were calculated, and the $p$-values $(<0.05)$ were calculated using Expression ${ }^{\mathrm{E}}$ software to refer to the differences between biological replicates.

\section{Gene ontology analysis}

The identified proteins were classified into different categories, as biological processes, cellular location, and molecular function in accordance with the information found in the Gene Ontology database, UniProtKB, and EBI GOA.

\section{Statistical analysis}

The data obtained concerning demographics and biochemical and anthropometric parameters were analyzed using R software Version 3.2.2 (2017). For the comparison of two means, Student's $t$-test was used for independent samples; otherwise, Mann-Whitney $U$ test was used. Correlations between variables were tested using Pearson and Spearman correlation tests. Data were considered significant with $p$-values $<0.05$. Figure 1 presents the experimental strategy used in this study. 


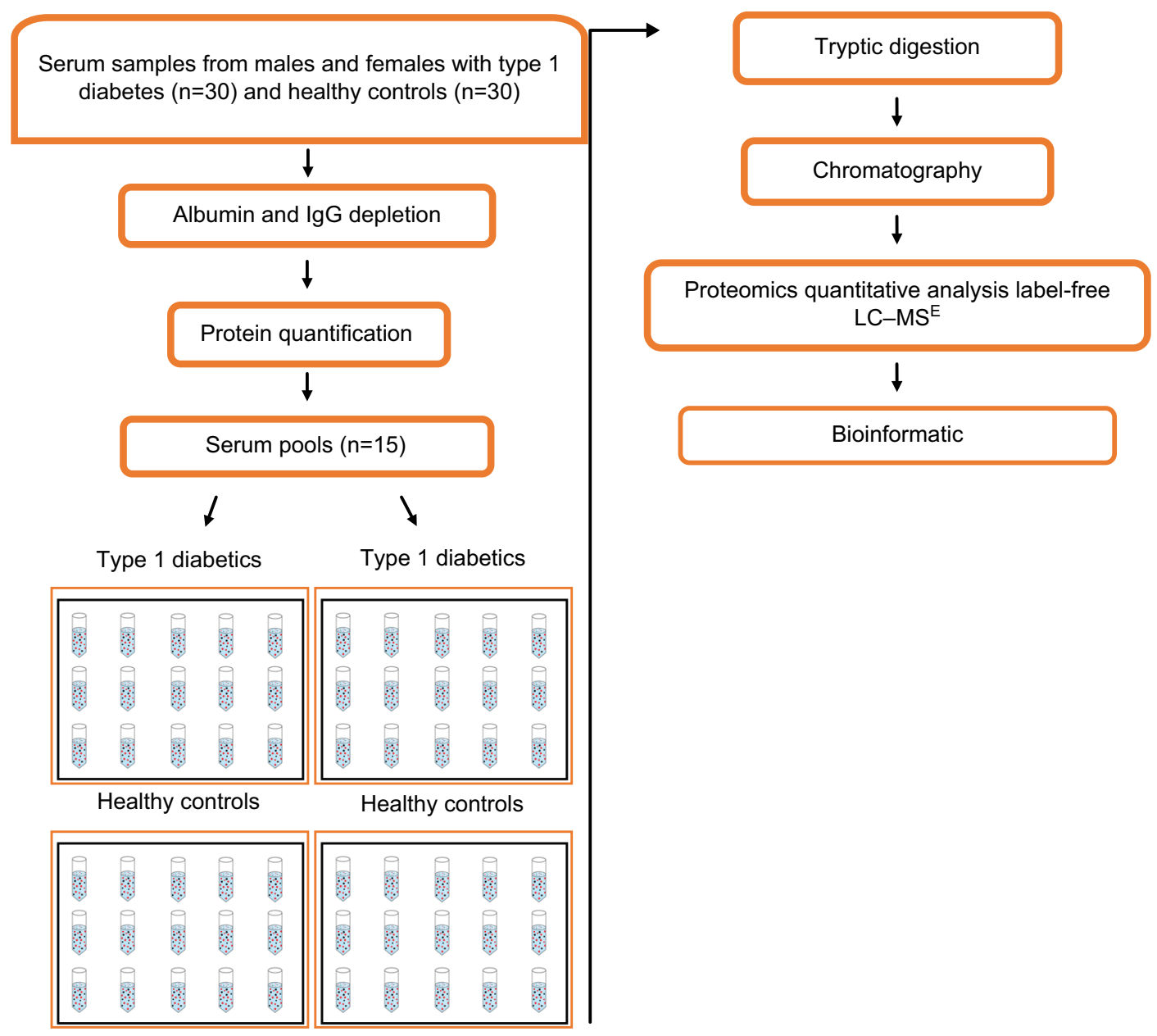

Figure I Diagram of the study design used for research of proteomic biomarker in the serum of individuals. Abbreviations: LC-MSE, liquid chromatography—data-independent label-free mass spectrometry; IgG, immunoglobulin G.

\section{Results}

\section{Clinical features}

A total of 60 individuals with an average age of $33.30 \pm 9.80$ years (ranging from 18 to 59 years) were studied and grouped into $30 \mathrm{DM} 1$ patients and $30 \mathrm{HC}$ individuals. Table 1 shows the biochemical and anthropometric characteristics of the patients enrolled for the study. DM1 and HC groups were matched, and there were no significant differences between the groups regarding age, gender, and BMI or in the serum concentrations of total cholesterol, HDL-C, LDL-C, total proteins, and creatinine. As expected, fasting blood glucose and C-peptide were significantly different between DM1 patients and HCs $(p<0.001)$. The DM1 group also exhibited a negative correlation between C-peptide and duration of disease $(r=-532 ; p<0.001)$. Moreover, no significant differences were observed between the groups relative to alcohol consumption and cigarette smoking status.

\section{Expression of proteins}

A comparative proteomic analysis was performed between DM1 and HC groups to investigate alterations in serum proteins in DM1 patients. In the current study, a total of 130 proteins were identified in the serum of the DM1 and HC groups in the total data set (Table S1). Eight proteins were differentially expressed in the serum of the DM1 group compared with the HC group (six proteins were upregulated and two were downregulated). Of the list of proteins identified, the criteria stated for the differential expression in each of the two biological replicates only considered proteins with differential expression (DM1/HC) with absolute ratios $>1.5$ (upregulated) and $<0.66$ (downregulated) and the levels of those proteins with ratios between 1.5 and 0.66 (unchanged). Based on gene ontology analysis, most of the proteins that were identified as related to molecular function were involved in binding (48\%), catalytic (12.35\%) and antioxidant (4.16\%) 
Table I Demographic, anthropometric, and clinical characteristics of participants in study

\begin{tabular}{|c|c|c|c|}
\hline Parameters & Patients with DMI & HC & $p$-value \\
\hline Subjects (n) & 30 & 30 & - \\
\hline Age (years) & $35.03(8.60)$ & $31.50(10.67)$ & $0.163^{\mathrm{a}}$ \\
\hline BMI $\left(\mathrm{kg} / \mathrm{m}^{2}\right)$ & $24.76(3.10)$ & $24.74(4.03)$ & $0.982^{\mathrm{a}}$ \\
\hline DMI duration (years) & $15.63(10.47)$ & - & - \\
\hline HbAlc (\%) & $7.5(1.2)$ & - & - \\
\hline Blood glucose (mg/dL) & I45.44 (56.96) & $89.93(6.02)$ & $<0.00 \mathrm{I}^{\mathrm{b}}$ \\
\hline Peptide C (ng/mL) & $0.14(0.17)$ & $3.92(0.56)$ & $<0.00 \mathrm{I}^{\mathrm{b}}$ \\
\hline Total cholesterol $(\mathrm{mg} / \mathrm{dL})$ & $179.68(39.12)$ & 192.56 (36.59) & $0.193^{\mathrm{a}}$ \\
\hline LDL (mg/dL) & $87.88(36.34)$ & $88.90(31.73)$ & $0.907^{a}$ \\
\hline $\mathrm{HDL}(\mathrm{mg} / \mathrm{dL})$ & $73.70(25.65)$ & $76.83(22.86)$ & $0.619^{a}$ \\
\hline TG (mg/dL) & $|4| .80(34.80)$ & $95.11(26.01)$ & $<0.00 \mathrm{I}^{\mathrm{b}}$ \\
\hline Total proteins (mg/dL) & $7.24(1.01)$ & $7.24(1.26)$ & $0.564^{b}$ \\
\hline Creatinine $(\mathrm{mg} / \mathrm{dL})$ & $0.91(0.21)$ & $0.92(0.23)$ & $0.863^{\mathrm{a}}$ \\
\hline Urea $(\mathrm{mg} / \mathrm{dL})$ & $33.03(11.47)$ & $25.97(7.72)$ & $0.007^{\mathrm{a}}$ \\
\hline \multicolumn{4}{|l|}{ Gender } \\
\hline Male n (\%) & $12(63.16)$ & $7(36.84)$ & $0.165^{\mathrm{a}}$ \\
\hline Female n (\%) & $18(43.90)$ & $23(56.10)$ & \\
\hline \multicolumn{4}{|l|}{ Smoking n (\%) } \\
\hline Yes & $2(66.67)$ & I (33.33) & I. $000^{\mathrm{b}}$ \\
\hline No & $28(49.12)$ & $29(50.88)$ & \\
\hline \multicolumn{4}{|l|}{ Drinking n (\%) } \\
\hline Yes & $0(0.00)$ & $\mathrm{I}(100.00)$ & I. $000^{\mathrm{b}}$ \\
\hline No & $30(50.85)$ & $29(49.15)$ & \\
\hline
\end{tabular}

Notes: Values are expressed as mean (SD) and number (percentage). aStudent's $t$-test; 'Mann-Whitney test; $p$-values $<0.05$ are considered significant. Abbreviations: BMI, body mass index; DMI, type I diabetes mellitus; HbAlc, glycated hemoglobin; HC, healthy controls; HDL, high-density lipoprotein; LDL, low-density lipoprotein; TG, triglycerides.

activities, and other functions. They also participated in biological processes related to regulation (19.81\%), cellular process (19.81\%), localization (14.12\%), stimulus response $(9.58 \%)$, and immune system $(9.75 \%)$, among others. In addition, the majority of proteins were located in the extracellular region (Figure 2). Table 2 shows the proteins identified as differentially expressed in the serum from DM1 group compared with HC group.

\section{Discussion}

Diabetes occurs as a result of a range of minor changes in protein expression that alters the stability of the health $\beta$-cell to a prediabetic phenotype of instability and possibly $\beta$-cell destruction. ${ }^{21}$ Thus, the proteomic analysis of protein expression is an important tool for understanding the molecular modifications associated with disease progression and may contribute to the therapeutic monitoring of this autoimmune disease.

In the present study, a proteomic approach using a labelfree quantitative MS analysis identified eight differentially expressed proteins in the serum of DM1 patients compared with HCs. All the proteins that were either upregulated (alpha-2-macroglobulin [ $\alpha 2 \mathrm{M}$ ], apolipoprotein A-II [ApoAII], $\beta 2$ glycoprotein I, Ig alpha-2 chain $\mathrm{C}$ region [IGHA2], alpha-1-microglobulin [AMBP], and prothrombin [THRB]) or downregulated (pregnancy zone protein [PZP] and complement $\mathrm{C} 4$ [C4]) are discussed below.

$\alpha 2 \mathrm{M}$ belongs to the $\alpha-\mathrm{M}$ family of proteins and is the largest major antiproteinase present in the plasma of vertebrates. ${ }^{22}$ In the present study, $\alpha 2 \mathrm{M}$ expression levels were upregulated in the DM1 group compared with HCs. In support of our data, Takada et al also showed that serum levels of $\alpha 2 \mathrm{M}$ were clearly upregulated in many individuals with DM1 and type 2 diabetes mellitus (DM2). ${ }^{23}$ Interestingly, upregulation of $\alpha 2 \mathrm{M}$ has been suggested as a potential biomarker for diabetic retinopathy and nephropathy, ${ }^{23-25}$ and studies have indicated that $\alpha 2 \mathrm{M}$ can also act as a binding and carrier protein for cytokines, including IL-I $\beta$ and IL-6, among others, ${ }^{26}$ leading to the induction of several defense reactions, such as immune response, acute phase reaction, and hematopoiesis. ${ }^{22}$ Therefore, acting as a carrier and binding protein could be the mechanism by which $\alpha 2 \mathrm{M}$ performs its immune functions, acting in inflammatory processes, and could explain its enhanced expression in the serum of people with DM1.

Proteomic analysis has shown upregulated expression levels of IGHA2 in DM1 patients. IGHA2 is an immunoglobulin that is a membrane-bound or secreted glycoprotein produced by B lymphocytes..$^{27}$ This immunoglobulin has an important 

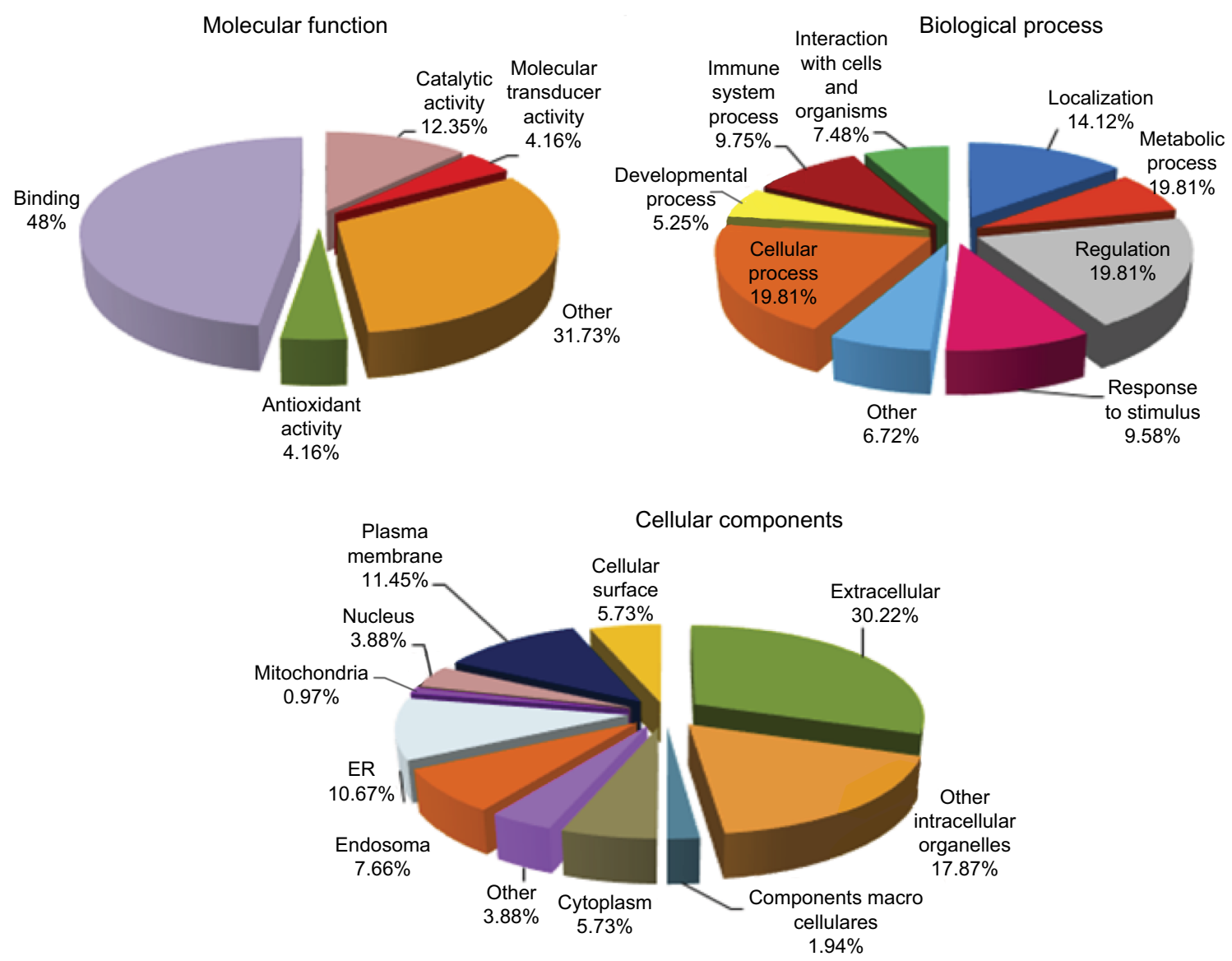

Figure 2 Percentage of serum proteins identified from albumin and immunoglobulin G depleted serum by LC-MSE for patients with type I diabetes and healthy controls based on their molecular function, biological process, and cellular components.

Abbreviations: ER, endoplasmic reticulum; LC-MSE, liquid chromatography-data-independent label-free mass spectrometry.

role in immune defense, especially at the mucosal surfaces. ${ }^{28}$ In our study, the high levels of IGHA2 identified are in keeping with previous reports that have shown increased concentrations of circulating IgHA2 in DM1 and DM2 patients. ${ }^{29-31}$ In DM1 patients, the increased expression in the serum of IGHA2 could be triggered in response to antigenic stimuli, forming continuous stimulation of antibody production. ${ }^{29}$ Moreover, the literature shows that the relationship between diabetes and IGHA2 has been described as involving advanced glycation products. Some studies reported a significant increase in the glycation of IGHA2 in the plasma of patients with DM1 and with complications of diabetes, especially in retinopathy, nephropathy, and neuropathy. ${ }^{32,33}$ In addition, a cross-sectional study reported that increased levels of IgA tended to be associated with hyperglycemia. ${ }^{34}$ In this context, it was suggested that high levels of IGHA2 result from an immune response to advanced glycosylation end products that increase and accumulate with persistent high blood glucose in patients with diabetes. ${ }^{31}$

ApoA-II expression levels were upregulated in the DM1 group compared with the HC group. APOA-II is the second most abundant apolipoprotein constituent of HDL, and the increased expression of APOA-II has been associated with several aspects of HDL, triglycerides, obesity, and insulin resistance. ${ }^{35,36} \mathrm{DM} 1$ patients often show lipid disorders, such as abnormalities in the regulation of plasma lipid metabolism, ${ }^{37}$ in different amounts of classes of lipoproteins, and in the transfer of lipids. ${ }^{38}$ Lipoprotein abnormalities might contribute to the development of atherogenesis and diabetic nephropathy. ${ }^{39,40}$ In fact, Soedamah-Muthu et al reported that a lower APOA-I to APO-II ratio in patients with microalbuminuria or macroalbuminuria could contribute to an increased risk of cardiovascular disease. ${ }^{41}$ Increased expression of APOA-II in transgenic mice showed enhanced HDL levels and increased size of HDL particles. Larger HDL observed is caused, in part, by the inhibition of the ability of hepatic lipase (HL) to hydrolyze phospholipids and triglycerides by APOA-II as well as an increased ratio of APOA-I to APOA-II. Therefore, interactions of APOA-II and APOA-I and HL influence the HDL structure and antiatherogenic properties. ${ }^{42,43}$ Furthermore, an excess of APOA-II in HDL may contribute to hypertriglyceridemia by inhibiting the 
Table 2 Characterization of differentially expressed proteins in serum of DMI patients compared with HCs as identified by LC-MSE

\begin{tabular}{|c|c|c|c|c|c|c|c|c|}
\hline $\begin{array}{l}\text { Accession } \\
\text { number }\end{array}$ & Protein name & $\begin{array}{l}\text { Molecular } \\
\text { weight }\end{array}$ & $\begin{array}{l}\text { Matched } \\
\text { peptides }\end{array}$ & $\begin{array}{l}\text { Coverage } \\
\text { (\%) }\end{array}$ & Score & DMI/HCa & Expression & Function \\
\hline POI023 & $\begin{array}{l}\text { Alpha-2- } \\
\text { macroglobulin }\end{array}$ & 163,291 & $66 / 95$ & 69.54 & $11,454.35$ & 1.64 & Up & Cellular process/regulation \\
\hline P02760 & Protein AMBP & 38,999 & $10 / 26$ & 37.78 & $2,146.99$ & 1.58 & Up & $\begin{array}{l}\text { Cellular process/process } \\
\text { metabolic/immune system }\end{array}$ \\
\hline P02652 & $\begin{array}{l}\text { Apolipoprotein } \\
\text { A II }\end{array}$ & $\mathrm{II}, 175$ & $6 / 11$ & 72.00 & $9,656.85$ & 1.84 & Up & $\begin{array}{l}\text { Cellular process/developmental } \\
\text { process/response to stimulus/ } \\
\text { metabolic process }\end{array}$ \\
\hline P02749 & $\begin{array}{l}\text { Beta-2- } \\
\text { glycoprotein I }\end{array}$ & 38,298 & $14 / 22$ & 62.03 & $4,930.08$ & 1.72 & Up & $\begin{array}{l}\text { Cellular process/localization/ } \\
\text { metabolic process/regulation }\end{array}$ \\
\hline P01877 & $\begin{array}{l}\text { Ig alpha-2 chain } C \\
\text { region }\end{array}$ & 36,526 & $15 / 22$ & 37.58 & $\mathrm{II}, 700.44$ & 2.14 & Up & $\begin{array}{l}\text { Cellular process/regulation/ } \\
\text { immune system }\end{array}$ \\
\hline P00734 & Prothrombin & 70,037 & $14 / 47$ & 35.69 & I,449.93 & 1.60 & Up & $\begin{array}{l}\text { Cellular process/developmental } \\
\text { and metabolic process/regulation/ } \\
\text { response to stimulus }\end{array}$ \\
\hline POCOL4 & $\begin{array}{l}\text { Complement } \\
\text { C4 A }\end{array}$ & 192,785 & $52 / 118$ & 54.59 & $5,352.24$ & 0.54 & Down & $\begin{array}{l}\text { Immune system/regulation/ } \\
\text { response to stimulus }\end{array}$ \\
\hline P20742 & $\begin{array}{l}\text { Pregnancy zone } \\
\text { protein }\end{array}$ & 163,863 & $16 / 87$ & 21.52 & I,774.43 & $0.4 I$ & Down & $\begin{array}{l}\text { Interaction with cells and } \\
\text { organisms }\end{array}$ \\
\hline
\end{tabular}

Notes: a Average differences of replicate samples run to type I diabetes patients compared with healthy control. Proteins are shown as I.5-fold differences either upregulated or downregulated $(p<0.05)$. Functions were assigned according to the String databases and literature search.

Abbreviations: AMBP, alpha-I-microglobulin; DMI, type I diabetes mellitus; HC, healthy control; LC-MSE, liquid chromatography-data-independent label-free mass spectrometry.

lipolysis of triglyceride-rich lipoproteins and by modifying the lipoprotein lipase activity. ${ }^{44}$ In diabetes, deficient function of insulin-dependent lipoprotein lipase may lead to hypertriglyceridemia as well as decreased HDL cholesterol levels due to increased lipid exchanges between triglyceride-rich lipoproteins and HDL. ${ }^{37}$ Nevertheless, studies using various approaches have described APOA-II as both proatherogenic and antiatherogenic; however, the role of this protein in lipid metabolism and atherogenesis is not well understood. Nevertheless, evidence supports the hypothesis that APOA-II is antiatherogenic, and further studies are required.$^{45}$ Taken together, these data indicate that APOA-II plays an important role in regulating lipid and $\beta$-cell metabolism. Thus, in the current study, our observation supports previous reports that show an association between apolipoproteins and DM1.

$\beta 2$ glycoprotein I, also known as apolipoprotein $\mathrm{H}$ (APOH), is involved in the inhibition of the intrinsic pathway of the activation of blood coagulation. There is evidence to support the association between APOH and lipid metabolism, inflammation, thrombosis, autoimmune disease, and atherosclerosis. ${ }^{46,47}$ Here, expression levels of APOH were upregulated in DM1 patients. The analysis of plasma levels of APOH from people with DM2 showed that patients with hypertriglyceridemia had significantly higher APOH values. ${ }^{46}$ Others studies have shown an association between $\mathrm{APOH}$ and diabetic retinopathy and found increased levels of APOH in the vitreous fluid of DM1 patients with proliferative diabetic retinopathy. ${ }^{48,49}$ However, to our knowledge, no study has yet shown increased levels of APOH in the serum of DM1 patients. Interestingly, APOH binds apoptotic cells in vivo, and this might trigger or enhance complement activation, thus facilitating the recognition and clearance of apoptotic cells. ${ }^{50}$ The role of APOH in the pathogenesis of diabetic retinopathy remains to be elucidated, but it could be related to complement activation or its potential role in the recognition of dying cells..$^{49}$ Although the relationship between cell apoptosis and autoimmunity remains to be fully established, there is evidence that T-cell-induced apoptosis is a mechanism in DM $1 .{ }^{51}$ Here, we show for the first time the upregulation of APOH in the serum of patients with DM1.

C4 was downregulated in the serum from patients with DM1. The complement system plays an important role in innate and acquired immunity, and evidence suggests that relevant target regulation of the complement system might be efficient in controlling autoimmune diseases. ${ }^{52}$ Abnormalities in complement proteins in DM1 patients have been reported, and reduced levels of $\mathrm{C} 4$ were attributed to hypercatabolism or reduction in protein synthesis. ${ }^{53}$ Moreover, decreased levels of $\mathrm{C} 4$ in children and adolescents with DM1 were related to impaired metabolic control. ${ }^{54}$ High glucose interferes with the innate function of the complement system and impairs the ability of the host to combat infection..$^{55}$ Deficiencies in $\mathrm{C} 4$ 
are strongly associated with autoimmunity humoral and lead to impaired humoral responses. ${ }^{52}$ Thus, the upregulation of C4 observed in this study is suggestive of loss of some functions of the complement system and thus increased risk of infectious processes and impaired metabolic control in DM1.

AMBP is a serum protein filtered by the glomerular membrane in the proximal tubule. ${ }^{56,57}$ Increased urinary excretion of this protein was observed in DM1 patients in the presence of microalbuminuria and normoalbuminuria. ${ }^{57}$ In this sense, new research has indicated some biomarkers that precede albuminuria and have been detected in both DM1 and DM2 patients with early renal dysfunction. ${ }^{58} \mathrm{AMBP}$ has been proposed as a biomarker of tubular dysfunction in the early stages of diabetic nephropathy and in the late stages of chronic kidney disease. ${ }^{59-62}$ Increased excretion urinary of AMBP has been frequently identified in patients with diabetes, compared with the control group. ${ }^{57}$ Increased levels of AMBP suggest that serum AMBP may play a role in the regulation of inflammatory processes, ${ }^{62}$ such as that occurs in diabetes. Interestingly, our study also showed that increased levels of AMBP occur in the serum proteome of DM1 patients, and to the best of our knowledge, this is the first study to observe this protein in serum from DM1 patients.

THRB is the protein precursor of thrombin, which plays a key role in thrombosis by converting fibrinogen to fibrin. ${ }^{63}$

Diabetes is associated with a number of changes in thrombotic and fibrinolytic coagulation factor level/activity, which collectively increase the risk of thrombus formation. ${ }^{63}$ Thrombin generation is enhanced in both DM1 and DM2 individuals, secondary to low-grade activation of the coagulation system. ${ }^{64}$ It has been suggested that elevated THRB levels can contribute both to thrombotic risk and to shortened clotting times in patients with diabetes. ${ }^{65}$ In this sense, hyperglycemia has been associated with enhanced thrombin production, and controlling glucose levels results in reduced thrombin generation, suggesting that hyperglycemia is prothrombotic. ${ }^{64}$ Conversely, hypoglycemia is also associated with enhanced clot formation. ${ }^{63}$ Here, we identified that THRB was upregulated in the serum of DM1 patients, which is an important component in the pathway of coagulation. This is in accordance with previous studies showing that this protein is suggestive of poorly controlled diabetes.

PZP was shown to be downregulated in the serum of DM1 patients compared with HCs. PZP is one of the most abundant pregnancy glycoprotein-associated plasma proteins with described immune inhibitory activities and is remarkably homologous to $\alpha 2 \mathrm{M} .{ }^{66,67}$ Several studies have suggested that PZP has immunosuppressive properties in pregnancy, indicating a role for this protein in maintaining immune tolerance to the fetus and equilibrating the maternal immune response. ${ }^{66,68}$ In fact, serum levels increase during gestation (up to $1,000 \mathrm{mg} / \mathrm{L}$ ). ${ }^{69}$ Furthermore, high serum levels of PZP have been observed in relation to some diseases, including inflammatory conditions, such as rheumatoid arthritis and also in people who later developed Alzheimer's disease. ${ }^{70,71}$ In the current study, we observed downregulation of PZP expression in the DM1 group compared with HCs. This finding is very relevant because, to our knowledge, this is the first report of low levels of PZP in the serum of DM1 patients. The reduction of this protein in DM1 patients suggests that there could be a suppression mechanism of it, thereby avoiding inhibition of the activation of T lymphocytes against the pancreatic $\beta$-cells. It has been suggested that PZP contributes to immune regulation by noncovalently sequestering a variety of other ligands such tumor necrosis factor- $\alpha$, IL-2, and IL- $6 .{ }^{72}$ In addition, Skornicka et al demonstrated that both native and activated PZP isoforms inhibited the activation of T-cell growth and IL-2 production. ${ }^{66} \mathrm{DM} 1$ is thought to involve chronic inflammation, leading to the release and increased activity of various immune system cells with a central role for $\mathrm{T}$ cells and macrophages. ${ }^{73}$ Studies have shown that some inflammatory markers are enhanced in individuals with DM1 compared with those without. ${ }^{74,75}$ Taken together, our results suggest that PZP could be a target for a potential DM1 therapy.

\section{Conclusion}

In conclusion, we used a proteomic approach with label-free $\mathrm{MS}^{\mathrm{E}}$ analysis as a strategy to discover differential protein profiles between the serum of patients with DM1 and HCs.

We identified proteins that were expressed in differential levels in the serum of patients with DM1 compared with HCs. In addition, to our knowledge, we described the first evidence for changes in expression levels of PZP and APOH in the serum of DM1 patients.

Our results showed differential expression of proteins related to immune system, lipid metabolism, and coagulation pathways, which may be correlated to the development and progression of DM1. Accordingly, these findings need to be fully investigated and validated in future studies.

\section{Acknowledgments}

This work was supported by funding from Biotechnology and Molecular Biology Laboratory from Ceará State University and the National Research Council for graduate student scholarships. The authors thank the scholars of scientific initiation: PS, LT, JC, and MH. 


\section{Author contributions}

All authors contributed toward data analysis, drafting and revising the paper and agree to be accountable for all aspects of the work.

\section{Disclosure}

The authors report no conflicts of interest in this work.

\section{References}

1. Milech A, Angelucci AP, Golbert A, et al. Diretrizes Da Sociedade Brasileira de Diabetes. 2015-2016th ed. Oliveira JEP de, Vencio S, editors. São Paulo: AC Farmacêutica; 2016. Available from: http://www.diabetes.org.br/profissionais/images/docs/DIRETRIZES-SBD-2015-2016. pdf.

2. Petersen KF, Shulman GI. Etiology of insulin resistance. Am J Med. 2006;119(5 Suppl 1):S10-S16.

3. Atkinson MA, Eisenbarth GS, Michels AW. Type 1 diabetes. Lancet. 2014;383(9911):69-82.

4. International Diabetes Federation. IDF Diabetes Atlas; 7th ed. 2015. Available from: http:/www.diabetesatlas.org. Accessed February 1, 2018.

5. World Health Organization. Global Report on Diabetes. 2016. Available in http://www.who.int/iris/handle/10665/204871. Accessed February 1, 2018.

6. American Diabetes Association (ADA). Standard of medical care in diabetes - 2017. Diabetes Care. 2017;40(Suppl 1):s4-s5.

7. Purohit S, She JX. Biomarkers for type 1 diabetes. Int J Clin Exp Med. 2008;1(2):98-116.

8. Sosenko JM, Krischer JP, Palmer JP, et al. A risk score for type 1 diabetes derived from autoantibody-positive participants in the diabetes prevention trial-type 1. Diabetes Care. 2008;31(3):528-533.

9. Chen CC, Lu YC, Chen YW, et al. Hemopexin is up-regulated in plasma from type 1 diabetes mellitus patients: role of glucose-induced ROS. J Proteomics. 2012;75(12):3760-3777.

10. Zhi W, Sharma A, Purohit S, et al. Discovery and validation of serum protein changes in type 1 diabetes patients using high throughput two dimensional liquid chromatography-mass spectrometry and immunoassays. Mol Cell Proteomics. 2011;10(11):M111.012203.

11. Sundsten T, Ortsater H. Proteomics in diabetes research. Mol Cell Endocrinol. 2009;297(1-2):93-103.

12. Neilson KA, Ali NA, Muralidharan S, et al. Less label, more free: approaches in label-free quantitative mass spectrometry. Proteomics. 2011;11(4):535-553.

13. Silva JC, Gorenstein MV, Li GZ, Vissers JP, Geromanos SJ. Absolute quantification of proteins by LCMS : a virtue of parallel MS acquisition. Mol Cell Proteomics. 2006;5(1):144-156.

14. SISVAN. Orientações Básicas Para a Coleta, Processamento, Análise de Dados E Informação Em Serviços de Saúde; 2004.

15. WHO Expert Committee on Physical Status: the use and interpretation of anthropmetry. Physical status: the use of and interpretation of anthropometry: report of a WHO expert committee. $1995 ; 854: 1-4520$.

16. World Health Organization. Global Status Report on Alcohol. Department of Mental Health and Substance Abuse. 2004.

17. Schoenborn CA, Adams PE. Health behaviors of adults: United States, 2005-2007. Vital Health Stat 10. 2010;(245):1-132.

18. Friedewald WT, Levy RI, Fredrickson DS. Estimation of the concentration of low-density lipoprotein cholesterol in plasma, without use of the preparative ultracentrifuge. Clin Chem. 1972;18(6): 499-502.

19. Bradford MM. A rapid and sensitive method for the quantitation of microgram quantities of protein utilizing the principle of protein-dye binding. Anal Biochem. 1976;72:248-254.
20. Li GZ, Vissers JP, Silva JC, Golick D, Gorenstein MV, Geromanos SJ. Database searching and accounting of multiplexed precursor and product ion spectra from the data independent analysis of simple and complex peptide mixtures. Proteomics. 2009;9(6):1696-1719.

21. Sparre T, Larsen MR, Heding PE, Karlsen AE, Jensen ON, Pociot F. Unraveling the pathogenesis of type 1 diabetes with proteomics: present and future directions. Mol Cell Proteomics. 2005;4(4):441-457.

22. Rehman AA, Ahsan H, Khan FH. Alpha-2-macroglobulin: a physiological guardian. J Cell Physiol. 2013;228(8):1665-1675.

23. Takada T, Kodera Y, Matsubara M, et al. Serum monomeric $\alpha 2$-macroglobulin as a clinical biomarker in diabetes. Atherosclerosis. 2013;228(1):270-276.

24. Caseiro A, Barros A, Ferreira R, et al. Pursuing type 1 diabetes mellitus and related complications through urinary proteomics. Transl Res. 2014;163(3):188-199.

25. Lu CH, Lin ST, Chou HC, Lee YR, Chan HL. Proteomic analysis of retinopathy-related plasma biomarkers in diabetic patients. Arch Biochem Biophys. 2013;529(2):146-156.

26. Athippozhy A, Huang L, Wooton-Kee CR, et al. Differential gene expression in liver and small intestine from lactating rats compared to age-matched virgin controls detects increased mRNA of cholesterol biosynthetic genes. BMC Genomics. 2011;12:95.

27. Schroeder HW, Cavacini L. Structure and function of immunoglobulins. J Allergy Clin Immunol. 2010;125(2 Suppl 2):S41-S52.

28. Woof JM, Russell MW. Structure and function relationships in IgA. Mucosal Immunol. 2011;4(6):590-597.

29. Triolo G, Giardina E, Zarcone MR, Giordano C, Rinaldi A, Bompiani GD. Contribution of secretory $\operatorname{IgA}$, polymeric $\operatorname{IgA}$ and $\operatorname{IgA} /$ secretory component-containing circulating immune complexes to the serum hyper-IgA in diabetes mellitus. Diabetologia. 1984;27(Suppl):157-159.

30. Figueredo A, Ibarra JL, Rodriguez A, et al. Increased serum levels of IgA antibodies to hsp70 protein in patients with diabetes mellitus: their relationship with vascular complications. Clin Immunol Immunopathol. 1996;79(3):252-255.

31. Rodriguez-Segade S, Camiña MF, Carnero A, et al. High serum IgA concentrations in patients with diabetes mellitus: agewise distribution and relation to chronic complications. Clin Chem. 1996;42(7):1064-1067.

32. Jaleel A, Halvatsiotis P, Williamson B, Juhasz P, Martin S, Nair KS. Identification of Amadori-modified plasma proteins in type 2 diabetes and the effect of short-term intensive insulin treatment. Diabetes Care. 2005;28(3):645-652.

33. Singh AK, Kingston JJ, Gupta SK, Batra HV. Recombinant bivalent fusion protein $\mathrm{rVE}$ induces CD4+ and CD8+ T-cell mediated memory immune response for protection against yersinia enterocolitica infection. Front Microbiol. 2015;6:1407.

34. Gonzalez-Quintela A, Alende R, Gude F, et al. Serum levels of immunoglobulins (IgG, IgA, IgM) in a general adult population and their relationship with alcohol consumption, smoking and common metabolic abnormalities. Clin Exp Immunol. 2007;151(1):42-50.

35. Castellani LW, Goto AM, Lusis AJ. Studies with apolipoprotein A-II transgenic mice indicate a role for HDLs in adiposity and insulin resistance. Diabetes. 2001;50(3):643-651.

36. Castellani LW, Nguyen CN, Charugundla S, et al. Apolipoprotein AII is a regulator of very low density lipoprotein metabolism and insulin resistance. J Biol Chem. 2008;283(17):11633-11644.

37. Feitosa AC, Feitosa-Filho GS, Freitas FR, Wajchenberg BL, Maranhão RC. Lipoprotein metabolism in patients with type 1 diabetes under intensive insulin treatment. Lipids Health Dis. 2013;12:15.

38. Pérez A, Caixàs A, Carreras G, et al. Lipoprotein compositional abnormalities in type I diabetes: effect of improved glycaemic control. Diabetes Res Clin Pract. 1997;36(2):83-90.

39. Vergès B. Lipid disorders in type 1 diabetes. Diabetes Metab. 2009;35(5): 353-360.

40. Overgaard AJ, Hansen HG, Lajer M, et al. Plasma proteome analysis of patients with type 1 diabetes with diabetic nephropathy. Proteome Sci. 2010;8:4. 
41. Soedamah-Muthu SS, Colhoun HM, Taskinen MR, Idzior-Walus B, Fuller JH; EURODIAB IDDM Complications Study Group. Differences in HDL-cholesterol:apoA-I + apoA-II ratio and apoE phenotype with albuminuric status in Type I diabetic patients. Diabetologia. 2000;43(11):1353-1359.

42. Hedrick CC, Castellani LW, Wong H, Lusis AJ. In vivo interactions of apoA-II, apoA-I, and hepatic lipase contributing to HDL structure and antiatherogenic functions. J Lipid Res. 2001;42(4):563-570.

43. Boucher J, Ramsamy TA, Braschi S, Sahoo D, Neville TA, Sparks DL. Apolipoprotein A-II regulates HDL stability and affects hepatic lipase association and activity. J Lipid Res. 2004;45(5):849-858.

44. Julve J, Muñoz García C, Santos D, Blanco-Vaca F, Escolà-Gil JC. La apolipoproteína A-II altera la composición apolipoproteica de HDL y su capacidad para activar la lipoproteína lipasa. Clin Investig Arterioscler. 2010;22(5):192-197.

45. Pownall HJ, Gillard BK, Gotto AM. Setting the course for apoAII: a port in sight? Clin Lipidol. 2013;8(5):551-560.

46. Castro A, Lázaro I, Selva DM, et al. APOH is increased in the plasma and liver of type 2 diabetic patients with metabolic syndrome. Atherosclerosis. 2010;209(1):201-205.

47. Gómez-Cardona EE, Hernández-Domínguez EE, Velarde-Salcedo AJ, et al. 2D-DIGE as a strategy to identify serum biomarkers in Mexican patients with type- 2 diabetes with different body mass index. Sci Rep. 2017;7:46536.

48. Ouchi Y, Yoshikawa E, Sekine Y, et al. Microglial activation and dopamine terminal loss in early Parkinson's disease. Ann Neurol. 2005;57(2): 168-175.

49. Simó R, Higuera M, García-Ramírez M, Canals F, García-Arumí J, Hernández C. Elevation of apolipoprotein A-I and apolipoprotein H levels in the vitreous fluid and overexpression in the retina of diabetic patients. Arch Ophthalmol. 2008;126(8):1076.

50. Chonn A, Semple SC, Cullis PR. Beta 2 glycoprotein I is a major protein associated with very rapidly cleared liposomes in vivo, suggesting a significant role in the immune clearance of "non-self" particles. J Biol Chem. 1995;270(43):25845-25849.

51. Lee SC, Pervaiz S. Apoptosis in the pathophysiology of diabetes mellitus. Int J Biochem Cell Biol. 2007;39(3):497-504.

52. Mizuno M, Suzuki Y, Ito Y. Complement regulation and kidney diseases: recent knowledge of the double-edged roles of complement activation in nephrology. Clin Exp Nephrol. 2018;22(1):3-14.

53. Charlesworth JA, Timmermans V, Golding J, et al. The complement system in type 1 (insulin-dependent) diabetes. Diabetologia. 1987;30(6): 372-379.

54. Liberatore RR, Barbosa SF, Alkimin Md, et al. Is immunity in diabetic patients influencing the susceptibility to infections? Immunoglobulins, complement and phagocytic function in children and adolescents with type 1 diabetes mellitus. Pediatr Diabetes. 2005;6(4):206-212.

55. Turina M, Fry DE, Polk HC. Acute hyperglycemia and the innate immune system: clinical, cellular, and molecular aspects. Crit Care Med. 2005;33(7):1624-1633.

56. Ekström B, Peterson PA, Berggárd I. A urinary and plasma $\alpha 1$-glycoprotein of low molecular weight: Isolation and some properties. Biochem Biophys Res Commun. 1975;65(4):1427-1433.

57. Soggiu A, Piras C, Bonizzi L, Hussein HA, Pisanu S, Roncada P. A discovery-phase urine proteomics investigation in type 1 diabetes. Acta Diabetol. 2012;49(6):453-464.
58. Gluhovschi C, Gluhovschi G, Petrica L, et al. Urinary biomarkers in the assessment of early diabetic nephropathy. J Diabetes Res. 2016;2016:1-13.

59. Pfleiderer S, Zimmerhackl LB, Kinne R, Manz F, Schuler G, Brandis M. Renal proximal and distal tubular function is attenuated in diabetes mellitus type 1 as determined by the renal excretion of alpha 1-microglobulin and Tamm-Horsfall protein. Clin Investig. 1993;71(12):972-977.

60. Varghese SA, Powell TB, Budisavljevic MN, et al. Urine biomarkers predict the cause of glomerular disease. JAm Soc Nephrol. 2007;18(3):913-922.

61. Aregger F, Uehlinger DE, Witowski J, et al. Identification of IGFBP-7 by urinary proteomics as a novel prognostic marker in early acute kidney injury. Kidney Int. 2014;85(4):909-919.

62. Korenkova V, Jones A, Hoy WE, Morais C, Cooper MA, Gobe GC. Urinary biomarkers for detection of early and advanced chronic kidney disease - a pilot study. Med Chem (Los Angeles). 2015;5(2):96-103.

63. Alzahrani S, Ajjan R. Review article: coagulation and fibrinolysis in diabetes. Diabetes Vasc Dis Res. 2010;7(4):260-273.

64. Ceriello A, Esposito K, Ihnat M, Zhang J, Giugliano D. Simultaneous control of hyperglycemia and oxidative stress normalizes enhanced thrombin generation in type 1 diabetes. J Thromb Haemost. 2009; 7(7):1228-1230.

65. Sauls DL, Banini AE, Boyd LC, Hoffman M. Elevated prothrombin level and shortened clotting times in subjects with type 2 diabetes. J Thromb Haemost. 2007;5(3):638-639.

66. Skornicka EL, Kiyatkina N, Weber MC, Tykocinski ML, Koo PH. Pregnancy zone protein is a carrier and modulator of placental protein-14 in T-cell growth and cytokine production. Cell Immunol. 2004;232(1-2): 144-156.

67. Devriendt K, Van den Berghe H, Cassiman JJ, Marynen P. Primary structure of pregnancy zone protein. Molecular cloning of a full-length PZP cDNA clone by the polymerase chain reaction. Biochim Biophys Acta. 1991;1088(1):95-103.

68. Stimson WH. Studies on the immunosuppressive properties of a pregnancy-associated alpha-macroglobulin. Clin Exp Immunol. 1976;25(2):199-206.

69. Folkersen J, Teisner B, Grunnet N, Grudzinskas JG, Westergaard JG, Hindersson P. Circulating levels of pregnancy zone protein: normal range and the influence of age and gender. Clin Chim Acta. 1981;110(2-3):139-145.

70. Horne CHW, Schoultz B, Towler CM, Damber MG, Stigbrand T, Gibb LM. Serum pregnancy-associated $\alpha_{2}$-glycoprotein levels in autoimmune diseases. Vox Sang. 1978;34(6):329-334.

71. IJsselstijn L, Dekker LJ, Stingl C, et al. Serum levels of pregnancy zone protein are elevated in presymptomatic Alzheimer's disease. J Proteome Res. 2011;10(11):4902-4910.

72. Wu SM, Pizzo SV. Mechanism of hypochlorite-mediated inactivation of proteinase inhibition by alpha 2-macroglobulin. Biochemistry. 1999;38(42):13983-13990.

73. Bending D, Zaccone P, Cooke A. Inflammation and type one diabetes. Int Immunol. 2012;24(6):339-346.

74. Snell-Bergeon JK, West NA, Mayer-Davis EJ, et al. Inflammatory markers are increased in youth with type 1 diabetes: the SEARCH case-control study. J Clin Endocrinol Metab. 2010;95(6):2868-2876.

75. Xiang Y, Zhou P, Li X, et al. Heterogeneity of altered cytokine levels across the clinical spectrum of diabetes in China. Diabetes Care. 2011;34(7): 1639-1641. 


\section{Supplementary material}

Table SI List of serum proteins between type I diabetes patients and healthy controls as identified by LC-MSE analysis

\begin{tabular}{|c|c|c|c|c|c|}
\hline $\begin{array}{l}\text { Accession } \\
\text { number }\end{array}$ & Protein name & $\begin{array}{l}\text { Molecular } \\
\text { weight }\end{array}$ & $\begin{array}{l}\text { Matched } \\
\text { peptides }\end{array}$ & Coverage (\%) & Score \\
\hline P43652 & Afamin & 69,069 & $4 / 61$ & 11.52 & 100.66 \\
\hline P02763 & Alpha-I-acid glycoprotein I & 23,512 & $9 / 17$ & 53.73 & $11,680.58$ \\
\hline PI9652 & Alpha-I-acid glycoprotein 2 & 23,603 & $8 / 19$ & 39.80 & $8,975.25$ \\
\hline PoI0II & Alpha-I-antichymotrypsin & 47,651 & $|6 / 3|$ & 45.63 & $4,340.51$ \\
\hline P01009 & Alpha-I-antitrypsin & 46,737 & $34 / 35$ & 62.44 & $13,832.54$ \\
\hline P04217 & Alpha-IB-glycoprotein & 54,254 & $8 / 26$ & 51.31 & $6,138.02$ \\
\hline P08697 & Alpha-2-antiplasmin & 54,566 & $7 / 34$ & 25.46 & 694.29 \\
\hline P02765 & Alpha-2-HS glycoprotein & 39,325 & $4 / 18$ & 50.68 & $2,842.23$ \\
\hline P01023 & Alpha-2-macroglobulin & $|63,29|$ & $66 / 95$ & 69.54 & $11,454.35$ \\
\hline P01019 & Angiotensinogen & 53,154 & $12 / 25$ & 35.26 & $4,547.05$ \\
\hline Q9UJ72 & Annexin AlO & 37,278 & $4 / 35$ & 10.19 & 134.28 \\
\hline P02647 & Apolipoprotein A I & 30,778 & $27 / 32$ & 68.54 & $29,954.64$ \\
\hline P02652 & Apolipoprotein A II & 11,175 & $6 / 11$ & 72.00 & $9,656.85$ \\
\hline P06727 & Apolipoprotein A IV & 45,399 & $12 / 42$ & 54.55 & $2,142.37$ \\
\hline P02656 & Apolipoprotein C III & 10,852 & $3 / 10$ & 36.36 & $12,643.42$ \\
\hline P05090 & Apolipoprotein D & 21,276 & $7 / 12$ & 30.69 & $1,265.36$ \\
\hline P02649 & Apolipoprotein E & 36,154 & $6 / 30$ & 20.19 & 350.88 \\
\hline P02749 & Beta 2 glycoprotein I & 38,298 & $14 / 22$ & 62.03 & $4,930.08$ \\
\hline Q9Y5Z0 & Beta secretase 2 & $56,|8|$ & $3 / 23$ & 9.46 & 140.23 \\
\hline P22792 & Carboxy peptidase $\mathrm{N}$ subunit 2 & 60,557 & $5 / 30$ & 13.03 & 334.61 \\
\hline O43866 & CD5 antigen like & 38,088 & $8 / 31$ & 43.80 & 614.25 \\
\hline Q7L2Z9 & Centromere protein $\mathrm{Q}$ & 30,595 & $4 / 28$ & 17.16 & 121.48 \\
\hline 043303 & Centriolar coiled coil protein of $110 \mathrm{kDa}$ & 113,424 & $9 / 80$ & 10.67 & 226.74 \\
\hline P00450 & Ceruloplasmin & 122,205 & $27 / 80$ & 57.28 & $3,369.44$ \\
\hline PI0909 & Clusterin & 52,495 & $12 / 36$ & 32.96 & $3,176.77$ \\
\hline P00748 & Coagulation factor XII & 67,792 & $4 / 40$ & 5.37 & 96.90 \\
\hline PI367I & Complement component $\mathrm{C} 6$ & 104,787 & $10 / 65$ & 9.31 & 159.79 \\
\hline P01024 & Complement $\mathrm{C} 3$ & 187,149 & $61 / 136$ & 51.41 & $8,628.71$ \\
\hline POCOL4 & Complement C4 A & 192,785 & $52 / 118$ & 54.59 & $5,352.24$ \\
\hline POCOL5 & Complement C4 B & 192,752 & $44 / 117$ & 48.57 & $5,333.65$ \\
\hline P0075। & Complement factor B & 85,533 & $23 / 64$ & 38.09 & $1,924.60$ \\
\hline P08603 & Complement factor $\mathrm{H}$ & 139,097 & $33 / 96$ & 40.70 & $\mathrm{I}, \mathrm{I} 55.49$ \\
\hline P05I56 & Complement factor I & 65,751 & $2 / 42$ & 5.49 & 117.71 \\
\hline P08।85 & Corticosteroid binding globulin & $45,|4|$ & $6 / 23$ & 27.90 & 371.10 \\
\hline P04003 & C4b binding protein alpha chain & 67,033 & $13 / 45$ & 30.82 & $\mathrm{I}, 198.6 \mathrm{I}$ \\
\hline A6NLW8 & Double homeobox protein A & 23,817 & $|/ 2|$ & 13.24 & 142.05 \\
\hline O43543 & DNA repair protein $X R C C 2$ & 31,957 & $2 / 19$ & 10.36 & 182.94 \\
\hline Q9NPGI & Frizzled 3 & 76,263 & $2 / 54$ & 6.16 & 148.64 \\
\hline P06396 & Gelsolin & 85,968 & $|7 / 5|$ & 32.86 & 661.02 \\
\hline Q96913 & Glycine $\mathrm{N}$-acyltransferase like protein I & 35,101 & $3 / 17$ & 11.26 & 149.87 \\
\hline Q13588 & GRB2 related adapter protein & 25,337 & $2 / 20$ & 26.27 & 389.12 \\
\hline 096020 & GI S specific cyclin E2 & 46,757 & $4 / 29$ & 11.88 & 105.55 \\
\hline P00738 & Haptoglobin & 45,205 & $27 / 28$ & 70.94 & $|7,966.3|$ \\
\hline P00739 & Haptoglobin related protein & 3,903 & $20 / 25$ & 46.26 & $7,405.70$ \\
\hline P69905 & Hemoglobin subunit alpha & 15,256 & $6 / 9$ & 76.76 & $3,268.27$ \\
\hline P6887। & Hemoglobin subunit beta & 15,998 & $7 / 13$ & 57.82 & $4,909.04$ \\
\hline P02042 & Hemoglobin subunit delta & 16,056 & $5 / 13$ & 29.25 & $4,275.18$ \\
\hline P02100 & Hemoglobin subunit epsilon & 16,203 & $2 / 14$ & 21.77 & $4,275.18$ \\
\hline P6989। & Hemoglobin subunit gamma I & 16,140 & $5 / 13$ & 40.82 & $4,306.96$ \\
\hline P69892 & Hemoglobin subunit gamma 2 & 16,126 & $4 / 13$ & 38.10 & $4,295.91$ \\
\hline P02790 & Hemopexin & 51,677 & $21 / 34$ & 50.87 & $16,740.46$ \\
\hline
\end{tabular}


Table SI (Continued)

\begin{tabular}{|c|c|c|c|c|c|}
\hline $\begin{array}{l}\text { Accession } \\
\text { number }\end{array}$ & Protein name & $\begin{array}{l}\text { Molecular } \\
\text { weight }\end{array}$ & $\begin{array}{l}\text { Matched } \\
\text { peptides }\end{array}$ & Coverage (\%) & Score \\
\hline P05546 & Heparin cofactor 2 & 57,071 & $7 / 36$ & 11.62 & 295.97 \\
\hline P04196 & Histidine rich glycoprotein & 59,578 & $12 / 33$ & 24.95 & $1,886.61$ \\
\hline PI7482 & Homeobox protein Hox B9 & 28,059 & $1 / 23$ & 15.20 & 155.80 \\
\hline P01876 & Ig alpha-I-chain C region & 37,655 & $20 / 23$ & 67.42 & $19,361.04$ \\
\hline P01877 & Ig alpha-2-chain $C$ region & 36,526 & $15 / 22$ & 69.41 & II,700.44 \\
\hline P01857 & Ig gamma I chain $C$ region & 36,106 & $9 / 21$ & 37.58 & $1,570.00$ \\
\hline P01859 & Ig gamma 2 chain $C$ region & 35,901 & $4 / 20$ & 17.18 & 300.21 \\
\hline P01860 & Ig gamma 3 chain $C$ region & 41,287 & $4 / 24$ & 12.20 & 702.83 \\
\hline P0186I & Ig gamma 4 chain $C$ region & 35,941 & $7 / 20$ & 33.94 & $\mathrm{I}, 236.5 \mathrm{I}$ \\
\hline P01766 & Ig heavy chain VIII region BRO & 13,227 & $4 / 6$ & 40.83 & $4,324.36$ \\
\hline P01767 & Ig heavy chain VIII region BUT & 11,906 & $1 / 8$ & 9.57 & 976.53 \\
\hline P0I774 & Ig heavy chain VIII region POM & 12,710 & $1 / 8$ & 15.97 & $2,043.78$ \\
\hline P0I777 & Ig heavy chain VIII region TEI & 12,559 & $2 / 6$ & 36.13 & $4,324.36$ \\
\hline P01765 & Ig heavy chain VIII region TIL & 11,612 & $2 / 6$ & 33.04 & $2,043.78$ \\
\hline P01779 & Ig heavy chain VIII region TUR & 12,188 & $\mathrm{I} / 7$ & 16.38 & $2,043.78$ \\
\hline P01776 & Ig heavy chain VIII region WAS & 12,847 & $2 / 7$ & 29.91 & $2,043.78$ \\
\hline P01763 & Ig heavy chain VIII region WEA & 12,142 & $1 / 6$ & 9.65 & 976.53 \\
\hline P0I764 & Ig heavy chain VIII region 23 & 12,582 & $2 / 8$ & 18.80 & 965.64 \\
\hline P0187I & Ig mu chain $C$ region & 49,307 & $25 / 38$ & 63.94 & $8,892.79$ \\
\hline P04220 & Ig mu heavy chain disease protein & 43,057 & $22 / 35$ & 52.94 & $12,444.26$ \\
\hline P01834 & Ig kappa chain $\mathrm{C}$ region & 11,609 & $7 / 7$ & 80.19 & $26,627.65$ \\
\hline P01614 & Ig kappa chain VII region Cum & 12,676 & $\mathrm{I} / 7$ & 11.30 & 787.52 \\
\hline P06309 & Ig kappa chain VII region GM607 Fragment & 12,664 & $2 / 5$ & 31.62 & 567.77 \\
\hline P06310 & Ig kappa chain VII region RPMI 64I0 & 14,707 & $2 / 7$ & 29.32 & 622.24 \\
\hline P06617 & Ig kappa chain $V$ II region TEW & 2,059 & $2 / 5$ & 32.74 & 571.31 \\
\hline P04206 & Ig kappa chain VIII region GOL & 11,830 & $2 / 8$ & 31.19 & I,520.77 \\
\hline PI8I35 & Ig kappa chain VIII region $\mathrm{HAH}$ & 14,073 & $2 / 8$ & 26.36 & $1,260.29$ \\
\hline PI8I36 & Ig kappa chain VIII region HIC & 14,089 & $2 / 7$ & 26.36 & $1,260.29$ \\
\hline P0162I & Ig kappa chain VIII region NG9 Fragment & 10,729 & $2 / 6$ & 56.00 & 590.59 \\
\hline P01620 & Ig kappa chain VIII region SIE & 11,775 & $4 / 6$ & 66.06 & $1,600.43$ \\
\hline P01623 & Ig kappa chain VIII region WOL & 11,746 & $3 / 7$ & 51.38 & $1,622.15$ \\
\hline P01622 & Ig kappa chain VIII region TI & 11,778 & $3 / 6$ & 51.38 & $\mathrm{I}, 520.77$ \\
\hline P04206 & Ig kappa chain VIII region GOL & 11,830 & $2 / 8$ & 31.19 & $\mathrm{I}, 520.77$ \\
\hline P0CG04 & Ig lambda I chain $\mathrm{C}$ region & 11,348 & $5 / 7$ & 65.09 & $38,924.68$ \\
\hline P0CG05 & Ig lambda 2 chain $C$ region & 11,294 & $6 / 7$ & 77.36 & $39,000.63$ \\
\hline P0CG06 & Ig lambda 3 chain $C$ region & 11,238 & $5 / 7$ & 76.42 & $39,000.63$ \\
\hline POCF74 & Ig lambda 6 chain $C$ region & 11,277 & $5 / 6$ & 77.36 & $24,818.13$ \\
\hline A0M8Q6 & Ig lambda 7 chain $C$ region & 11,303 & $4 / 7$ & 46.23 & $24,610.28$ \\
\hline P0I59I & Immunoglobulin J chain & 18,099 & $4 / 11$ & 34.59 & $\mathrm{I}, 818.20$ \\
\hline P35858 & $\begin{array}{l}\text { Insulin like growth factor binding protein } \\
\text { complex acid labile subunit }\end{array}$ & 66,035 & $6 / 35$ & 12.56 & 119.96 \\
\hline B9A064 & Immunoglobulin lambda like polypeptide 5 & 23,063 & $6 / 12$ & 42.99 & $38,934.43$ \\
\hline PI 9827 & Inter-alpha trypsin inhibitor heavy chain $\mathrm{HI}$ & 101,389 & $19 / 56$ & 31.61 & $\mathrm{I}, 735.56$ \\
\hline PI9823 & Inter-alpha trypsin inhibitor heavy chain $\mathrm{H} 2$ & 106,464 & $21 / 70$ & 32.77 & $\mathrm{I}, 4 \mid 5.98$ \\
\hline Q14624 & Inter-alpha trypsin inhibitor heavy chain $\mathrm{H} 4$ & 103,358 & $22 / 64$ & 40.00 & $1,410.90$ \\
\hline Q5T749 & Keratinocyte proline rich protein & 64,136 & $1 / 29$ & 9.33 & 133.79 \\
\hline P01042 & Kininogen I & 71,958 & $|3 / 6|$ & 39.13 & $\mathrm{I}, 470.83$ \\
\hline P02750 & Leucine-rich alpha-2-glycoprotein & 38,178 & $6 / 24$ & 26.80 & 925.55 \\
\hline 015165 & $\begin{array}{l}\text { Low-density lipoprotein receptor class A } \\
\text { domain containing protein }\end{array}$ & 33,900 & $2 / 19$ & 12.42 & 142.67 \\
\hline Q96PD5 & $\mathrm{N}$ acetylmuramoyl $\mathrm{L}$ alanine amidase & 62,217 & $7 / 36$ & 23.61 & 381.10 \\
\hline Q13516 & Oligodendrocytetranscriptionfactor2 & 32,385 & $2 / 16$ & 20.74 & 356.38 \\
\hline P05।55 & Plasma protease $\mathrm{Cl}$ inhibitor & 55,154 & $7 / 29$ & 21.60 & $\mathrm{I}, 325.77$ \\
\hline P00747 & Plasminogen & 90,569 & $15 / 63$ & 26.91 & 318.40 \\
\hline P02775 & Platelet basic protein & 13,894 & $3 / 9$ & 46.09 & 801.19 \\
\hline
\end{tabular}

(Continued) 
Table SI (Continued)

\begin{tabular}{|c|c|c|c|c|c|}
\hline $\begin{array}{l}\text { Accession } \\
\text { number }\end{array}$ & Protein name & $\begin{array}{l}\text { Molecular } \\
\text { weight }\end{array}$ & $\begin{array}{l}\text { Matched } \\
\text { peptides }\end{array}$ & Coverage (\%) & Score \\
\hline P20742 & Pregnancy zone protein & 163,863 & $16 / 87$ & 21.52 & $\mathrm{I}, 774.43$ \\
\hline P02760 & Protein AMBP & 38,999 & $10 / 26$ & 37.78 & $2,146.99$ \\
\hline Q9UJC3 & Protein Hook homolog I & 84,648 & $8 / 69$ & 13.87 & 65.59 \\
\hline P00734 & Prothrombin & 70,037 & $14 / 47$ & 35.69 & $1,449.93$ \\
\hline Q9H5L9 & Putative uncharacterized protein $\mathrm{C} 5$ orf66 & $\mathrm{I}, 557$ & $\mathrm{I} / 8$ & 24.83 & 115.20 \\
\hline 000472 & RNA polymerase II elongation factor ELL2 & 7,232 & $5 / 74$ & 9.69 & 163.86 \\
\hline Q9NP77 & $\begin{array}{l}\text { RNA polymerase II subunit A C terminal } \\
\text { domain phosphatase SSU72 }\end{array}$ & 22,575 & $7 / 17$ & 43.30 & 179.28 \\
\hline Q96HSI & $\begin{array}{l}\text { Serine threonine protein phosphatase PGAM5 } \\
\text { mitochondrial }\end{array}$ & 32,005 & $3 / 23$ & 11.76 & 229.10 \\
\hline P02787 & Serotransferrin & 77,064 & $42 / 76$ & 72.78 & $42,299.91$ \\
\hline P02768 & Serum albumin & 69,367 & $54 / 55$ & 38.92 & $4,317.47$ \\
\hline P27I69 & Serum paraoxonase arylesterase I & 39,731 & $7 / 18$ & 50.99 & $2,611.12$ \\
\hline P04278 & Sex hormone binding globulin & 43,779 & $4 / 29$ & 25.62 & 210.35 \\
\hline 000337 & Sodium nucleoside cotransporter & 71,584 & $3 / 35$ & 3.39 & 102.95 \\
\hline Q13596 & Sortingnexin I & 5,907 & $3 / 40$ & 11.88 & 178.19 \\
\hline O60235 & Transmembrane protease serine IID & 46,264 & $2 / 20$ & 11.48 & 122.25 \\
\hline P02766 & Transthyretin & I5,887 & $4 / 9$ & 50.34 & 302.37 \\
\hline Q9NZQ9 & Tropomodulin 4 & 39,336 & $3 / 32$ & 26.09 & 192.01 \\
\hline Q5SQH8 & Uncharacterized protein C6orf 136 & 35,794 & $2 / 16$ & 29.84 & 122.10 \\
\hline Q8N865 & Uncharacterized protein C7orf 31 & 68,465 & $4 / 49$ & 12.03 & 47.34 \\
\hline Q6UXV3 & Uncharacterized protein UNQ6I26 & 16,883 & $\mathrm{I} / 8$ & 36.31 & $|6| .4 \mid$ \\
\hline P02774 & Vitamin D binding protein & 52,964 & $24 / 45$ & 67.93 & $3,508.70$ \\
\hline P04004 & Vitronectin & 54,306 & $10 / 28$ & 38.49 & $2,808.10$ \\
\hline P253II & Zinc alpha-2-glycoprotein & 34,259 & $9 / 27$ & 48.66 & $2,246.30$ \\
\hline P2I506 & Zinc finger protein 10 & 66,455 & $4 / 45$ & 9.60 & 220.02 \\
\hline Q86UK7 & Zinc finger protein 598 & 98,637 & 6/7I & 10.18 & 161.99 \\
\hline
\end{tabular}

Abbreviations: AMBP, alpha-I-microglobulin; LC-MSE, liquid chromatography-data-independent label-free mass spectrometry.

Diabetes, Metabolic Syndrome and Obesity: Targets and Therapy is an international, peer-reviewed open-access journal committed to the rapid publication of the latest laboratory and clinical findings in the fields of diabetes, metabolic syndrome and obesity research. Original research, review, case reports, hypothesis formation, expert opinion and commentaries are all considered for publication. The manuscript management system is completely online and includes a very quick and fair peer-review system, which is all easy to use. Visit http://www.dovepress.com/testimonials.php to read real quotes from published authors.

Submit your manuscript here: https://www.dovepress.com/diabetes-metabolic-syndrome-and-obesity-targets-and-therapy-journal 